\title{
The Effect of Student Centered Learning Model in Achievement of Biology Subject for Second Graders and Reasoning Thinking
}

\author{
Dr. Saleem Tawfeeq Ali Naser \\ Baghdad University College of Education, Pure Science - Ibn al- Haytham
}

\begin{abstract}
This study was conducted in Baghdad targeted The Effect of Student Centered learningModel in Achievement of Biology Subject for Second graders average and Reasoning Thinked for the academic year 2015/2016. Sample was divided into two divisions randomly represent one of the experimental group (30students) studied of student Centered Learning and represented the second Division of Control group (30 students) I studied the usual way has group in chronological age in months and biogenic information and academic achievement former biology and scalc scientific thinking. The researcher prepared achievement test consisted final from of (40) items were verified optional virtual honesty and sincerity content was difficult to the find the strength and modulus discrimination paragraphs and find stability reached (0-82) and the adoption of a measure research ready after confirmation of sincerity andpersistence the results were as follows:-1. Out weigh the experimental group to their peers in the control group variable collection. 2. Out weigh the experimental group to their peers in the control group variable Reasoning Thinking.
\end{abstract}

Keywords: reasoning, thinking, control group

\section{Research Problem}

Problem Our current era is characterized by rapid development in all areas of scientific and technological life. Therefore, the individual must possess an intellectual basis capable of facing scientific and technological progress, while our educational institutions are still interested in receiving information and knowledge.Research Problem. Our current era is characterized by rapid development in all areas of scientific and technological life. Therefore, the individual must possess an intellectual basis capable of facing scientific and technological progress, while our educational institutions are still interested in receiving information and knowledge.

This was confirmed by interviewing the researcher of a number of biology teachers who have served for ten years and more and discussed the methods and methods adopted in teaching. He concluded that the methods and methods followed are characterized by the nature of the nonindependent without attention to the development of the student's cognitive abilities Then the greatest effort on the teacher to prepare the material and delivery to the learner while the role of the learner negatively is listening and teaching and keeping the educational material. As for the modern methods, the role of the learner is active and in light of that the researcher believes that the model of learning and education is thatRoger the human in learning based on the learner himself may lead to raising the level of study and the development of their reasoning has identified the problem of research by the following question - What impact of learning based on the learner in the collection of biology in the second grade students and the average reasoning?

\section{Research Importance}

The importance of current research of the scientific knowledge in the field of science, including the revival of a large and therefore must be adopted scientific education, which represents one of the aspects of modern education to provide the learner information, concepts and principles in the field of different natural sciences.

Natural sciences have been and continue to be the most important aspects of human life, and what a country offers in this field is a standard that measures scientific progress and determines its place among nations and countries (Huwaydi, 2005). Modern education believes that the school should be a true picture of the reality of society.The study materials should be designed to help solve the problems facing the learner in his / her community. (Al-Esawi, 2008). 37 The contemporary trend in science teaching asserts that evolution must aim to understand the content of science, the methods used by scientists to access this content,And methods that can be followed in his teaching (Ambo Saidi and Balushi, $20115)$

The student is a key factor in the learning process, so the interest in the subject is not limited to attention to the student. The student learns nothing but if he finds himself motivated to do so.

And the achievement of this thing was related to meeting the needs of his needs (Zidane, 2008, 204). The human theory espoused by Roger Rogers, which established that the student is an active and active object, plays an important and essential role in arriving at knowledge through its preparation,And its potential and potentials, which it highlights in educational settings and situations, drawing on its previous and direct experience. The researcher believes that the role of the student in reaching knowledge and adoption through his tendencies and abilities and relying on previous experience direct and indirect that Can contribute to the raising of educational achievement and the development of reasoning and highlight the importance of research from the importance of adopting the model of learning based on the learner, which showed its effectiveness in the orientation towards the student and his 


\section{International Journal of Science and Research (IJSR) \\ ISSN (Online): 2319-7064}

Index Copernicus Value (2016): 79.57 | Impact Factor (2015): 6.391

readiness and guidance and his own experiences affect positively in his behavior and collectionand his educational achievement and the development of his reasoning.

\section{Aims of the Research}

The current research aims at identifying the effect of learnerbased learning in the achievement of biology among secondgrade students and their reasoning. In order to achieve the goal of the research, the two hypotheses were formulated.

1) There is no statistically significant difference at the level of $(0,05)$ between the average score of students of the experimental group. Who studied according to the learning model based on the learner and the average score of students of the control group who studied according to the usual method in the test collection of Biology.

2) There were no statistically significant differences at the level of $(0,05)$ between the average score of the students of the experimental group who studied according to the learning model based on the learner and the average score of the students of the control group who studied according to the normal method in the scale of indicative thinking.

\section{Limits of the Research}

The current research is determined by the following:

1) The average second grade students in the middle and secondary schools of the Directorate General of Baghdad Education / Karkh / 3 for the academic year 2015-2016.

2) The second semester of the academic year 2015-2016.

3) Chapter Seven, Eighth and Ninth, I-5 of the year 2014. 4. The trial lasted from Sunday 21/2/2016 to Thursday $5 / 5 / 2016$

\section{Definition of Terms}

1. Learner - Centered Learning: (Rogers, 1983) defined it as an indirect model of learning that includes the development of positive attitudes, warmth and acceptance towards the student. The teacher encourages the learner to show his feelings and ideas by looking for the experiences he has to be able to make the decision in what he learnsor objecting to educational problems, and establishing a friendly relationship with him without providing him with information or instructions, leaving a positive impact on him and creating an atmosphere of self-initiative, learning experience and sympathetic understanding. (Rogers, 1983, p 273).

But (Adas et al., 2002) defined it as learning that aims at respecting and respecting the learner, and helping him to grow to the maximum of his developmental potential, which is learning which means emotional and personal aspects. As defined by the same source as learning that aims to help the studentTo make a decision about what they are experiencing, interact with and learn. (Adas et al., 2002, 668) (known by Abu Jado, 2009) as a state of mind characterized by the inability of the owner to distinguish between self and subject and between the ego and existing objects. (Abu Jadu, 2009).
The procedural definition of Lerner - Centered Learning

is learning that aims to help intermediate second grade students to express their ideas and interact with the learning process by respecting their abilities and making a decision regarding all the educational situations that are exposed in the biology according to Roger's model in learning which identified in five steps.

\section{Achievement}

In (2006) is defined as a tool used to determine the learner's gain from information, trends and trends in a subject he has learned formally by answering a sample of questions that represent the content of the course material. (Khadr, 2006 $373)$.

But (Alderman, 2007) as 'proving the ability to achieve the learning experiences that have been developed for him' (Alderman, 2007, p 101)

3. Abu Gado (2009) that 'the outcome of what the student learns after a period of time and can be measured by the degree to which the student obtains by the student and takes the test of achievement. (Abu Jado, 2009 :425).

\section{The procedural definition of Achievement}

Is the outcome of the learner's knowledge, knowledge and skills as measured by the grades in the achievement test for the sample students during the academic year.

\section{Reasoning Thinking}

(Reasoning Thinking), which was defined as a mental process that involves putting information, attitudes or experiences in an orderly manner, leading to a logical conclusion or leading to a resolution or solution of a problem. (Said, 2007 191).

Madkhalee, 2009 as one of the types of scientific thinking in which learners come from known and correct information to know the unknown, or by applying a certain rule to partial cases. (Madkhalee, 2009, 13).

Bader (2010) is a logical process that includes a set of subskills, through which students can take advantage of the available information in the detection of new results by walking down the lines of conclusion and linking each cause with a result. And is measured in the final grade obtained by students in the test prepared for this purpose (Badr, 2010, 127).

\section{The procedural definition of reasoning thinking}

is a mental process through which the learner can arrive at the correct answer through the data of the question and the conclusion of certain facts and is measured by the degree to which the students obtain the sample of the research in the reasoning test.

\section{Learning theory based on the learner}

This type of learning seeks to develop the personality of the learner and his ability to solve problems and improve his competence to perform his social role effectively. Sometimes called (facilitating learning). 


\section{International Journal of Science and Research (IJSR) \\ ISSN (Online): 2319-7064}

Index Copernicus Value (2016): 79.57 | Impact Factor (2015): 6.391

The learner plays a key role in choosing his or her educational goals according to his / her needs and learning the degree of his / her learning through self-evaluation. This will make the learner learn the truth and self-esteem and gain self-confidence effectively (Al-Khawla, 1995, 341).

\section{The student's role in learner-based learning}

The student's self-confidence as a free, vital, active, effective and cooperative person living in social conditions that respects his ideas to be his direct role in educational situations, teachers and supervisors are indirect role and this is the view of the human direction ofThe student's role can be defined as:

1) Expressing ideas, initiative, activity and vitality in attitudes.

2) Understand the self by practicing the foresight of the situation and the problem.

3) Adhering to the standards and rules of the open class to play an important role in it.

4) His role is socially active with the individuals around him.

5) Have a role in planning the position of learning and place, place and time.

6) Practice experience and interactive learning based on experience. (Katami et al., 1994, 415).

It is clear that the learner plans and sets goals and materials and methods of assessment and provide an atmosphere of respect and appreciation of the abilities of the learner and thus moved attention and focus from the textbook and educational material and teacher to the attention of the student and the focus of classroom learning. (Qatami and Naifah, 1998).

The role of the teacher in learning based on the learner the teacher requires to provide an atmosphere of freedom of learning as learning is a natural state needed by the learner in accordance with his interest in the threat. Learning is selfinitiated in a challenging environment for indirect learning. (Rogers, 1985, p. 225).

The teacher's role in the human direction is to facilitate learning through guidance and to provide learning experiences. (Badawi, 2009). The teacher is therefore an important part of the learning process by accepting the ideas of the learners, nurturing their feelings, and creating the right atmosphere for learning (Qatami and Naifah, 1998). Therefore, the learner is more aware and receptive and will have the ability to problems. (Biehler, R, * Snowman, 1990, p. 483) refers (Adas et al., 2002).

The role of the teacher in effective education can be determined in the light of the human direction as follows:

1) Directing education and providing opportunities and encouraging learners in learning situations and management.

2) Try to create a positive atmosphere.

3) Make an effort to encourage and assist students.

4) Support the feelings of learners towards educational attitudes.

5) Encourage learners to participate in difficult activities and situations.

6) Help students develop their positive feelings.
7) Develop a strategy that illustrates the values of the society in which learners live.

8) Provide learners with educational experiences to develop desirable habits and attitudes. 9. Topics of lessons taught to learners to deliver what they want.

9) Show a humanistic model Learners feel the sense of others. (Adass et al., 2002 646).

Rogers identified three trends in the development of good teacher-student relationships to facilitate the possibility of learning

1) Realism is the ability of the teacher to communicate feelings to students to have a real person can refer to in various things.

2) Acceptance The teacher's view of the student includes interest, trust and respect, which creates an emotional social atmosphere that encourages learning.

3) Empathic Underling Standing: A student's sense that the teacher understands what the student is thinking. This empathy based on understanding, communicated with clarity and precision, will increase positive relationships, positive social climate and effective learning. (AlBasafah, 2006 226).

\section{Steps of Learner-Based Learning Model According to Rogers}

1) The teacher provides a comfortable psychological atmosphere to help learners interact with the educational situations they are exposed to.

2) Determine the problem that learners want to learn and disclose their dimensions.

3) Discuss the problem by the learners and guide the teacher if the situation calls for it.

4) Teachers will outline the plan they will follow to resolve the problem they are interacting with.

5) The learners' total awareness of the subject of learning under the guidance of the teacher. (Al-Khawaldeh et al., $1995,342)$.

\section{Reasoning Thinking}

Is the mental activity of the brain as a response to the millions of visual and invisible stimuli received by the five senses. (Abdel Aziz, 2009 22) Inference in the language means to provide evidence to prove a particular thing a conceptual process of thinking includesplacing facts or information in an organized manner leads to the conclusion or solution of a problem. (Al-Najdi et al., 2005, 39) Interference requires the intervention of mental processes such as remembering, imagining, judgment, understanding, foresight, abstraction, assessment, reasoning, planning, discrimination, analysis and criticism.(Hamshari, 2001 137). And thinking reasoning is one of the types of thinking purposeful, which we seek on the way to reach a result or a solution or fact and therefore needs to a degree of information so that we can reach the result after analysis and synthesis, and reasoning thinking is a method that enters most of the teaching methods.

If we follow the movement of the mind is the process of inference, it goes through steps parallel to the steps of the scientific approach to the theories and laws where the

\section{Volume 6 Issue 12, December 2017}




\section{International Journal of Science and Research (IJSR) \\ ISSN (Online): 2319-7064}

Index Copernicus Value (2016): 79.57 | Impact Factor (2015): 6.391

learner to the characteristics of the situation using his previous experiences. (Ahmed, 1973 284).

\section{Deduction thinking types}

1) Deductive deduction is represented in the transition of the individual in his thinking from the general to the private which is deduced from the whole to the part. (Pleasure, 2005 211)

2) Inductive inference is the transmission of thinking in partial judgments or individual cases to a general rule applicable to all similar or similar situations. (Waqf, 1998 499).

3) The deductive reasoning is to arrive at knowledge by using a new idea which is not present in the proposals, ie, to extract new information.

\section{Previous Studies}

First studies on the Rogers model (for learner-based learning) :

1) The study of Sagher and Saleh (2002). This study was conducted in the Kingdom of Saudi Arabia (Riyadh) and aimed to identify the practices of teaching teachers in primary and secondary education, Which can be made in the light of learning theories. The sample consisted of (350) teachers randomly selected and adopted a questionnaire to measure teacher teaching practices consisting of 18 words in three axes (behavioral, cognitive and human). After the results were treated statistically, the results showed that teachers' teaching practices were based more on human theory than on other theories.

2) Albaweey and Mahdee :The study was conducted at the universities of Baghdad and Qadissiya. The aim of this study was to uncover the teaching practices of university faculty members and their knowledge in light of the humanization of education from the point of view of their students. The sample consisted of (650) randomly chosen students.

3) Alafoon and Batol (2007/2008). This study was conducted in Baghdad and aimed to demonstrate the effectiveness of the learning model based on the learner in the achievement of students in the second grade and their motivation to learn biology. The sample consisted of (39) students distributed in two experimental groups and control. The study based on the measure of motivation towards the biology component of (30) paragraph and after the treatment of the results statistically showed the results for the benefit of the experimental group.

\section{Studies dealing with reasoning thinking}

1.The study of Khazraji (2009) This study was conducted in Iraq and aimed to know the effect of the model of constructive learning and cooperative learning in modifying the misconception of physical concepts and reasoning thinking among the students of the Institute of preparing teachers. The study sample consisted of (60) female students who were divided into three equal groups. The researcher prepared the conceptual test and the choice of reasoning.
The statistical analysis using ANOVA and T-test showed no statistically significant difference between the groupBetween the first and second experimental groups in the post-conceptual selection. The first experimental group exceeded the second in the test of reasoning and the second experimental group exceeded the control group in the reasoning test. It means the superiority of the first and second experimental groups on the control in the test of reasoning thinking.

3.2. Abadah, (2013) $\mathrm{m}$. This study was conducted in Iraq and aims to know the effect of the reciprocal teaching strategy in the achievement of the first grade students in mathematics and their reasoning. The researcher used the experimental method of partial adjustment of two equal groups. The study sample consisted of (50) students who were randomized in the form of two equal groups (experimental and experimental). The methods used were the cognitive test and the reasoning test. The researcher used the statistical methods.

The results of the study showed that there were statistically significant differences in favor of the experimental group in the achievement test and in the post-induction reasoning test.

\section{Indicators and semantics of previous studies}

Previous studies on learner-based learning revealed several objectives, including the effectiveness of learner-based learning in the practices of faculty members from the point of view of their students, including the superiority of the experimental group studied by using the effectiveness of learning based on the learner. Studies on reasoning have also revealed the superiority of the experimental group to the choice of reasoning and the test of achievement. The present study may or may not be consistent with previous studies in high achievement and level of thinking.This will be demonstrated through the application of the experiment and the researcher will present the results and compare them with the results of previous studies later.

\section{The procedures of the research}

the procedures of the research will be presented to the procedures of selecting the experimental design and identify the research community and choose the sample and the equivalence of groups and the preparation of research requirements and tools and the application of experience and then the application of research tools and the review of statistical means in the analysis of research data.

First:Experimental Design The current research includes one independent variable, learner-based learning and two variables (achievement) and (reasoning). The researcher chose the experimental design with partial control of two sets,Experimental Design The current research includes one independent variable, learner-based learning and two variables (achievement) and (reasoning). The researcher chose the experimental design with partial control of two sets, One of them is an control group and the other is an experimental with a post-test as in the scheme (1). 
International Journal of Science and Research (IJSR)

ISSN (Online): 2319-7064

Index Copernicus Value (2016): 79.57 | Impact Factor (2015): 6.391

Schema (1) experimental design for research

\begin{tabular}{|c|c|c|c|c|}
\hline Post test & dependent variable & Independent variable & Equivalence & group \\
\hline $\begin{array}{l}\text { The achievement of the } \\
\text { reasoning test. }\end{array}$ & $\begin{array}{l}\text { Collective } \\
\text { reasoning }\end{array}$ & $\begin{array}{l}\text { Learner - based } \\
\text { learning }\end{array}$ & $\begin{array}{l}\text { 1) Life Time } \\
\text { 2) Previous Information } \\
\text { 3) Previous Test } \\
\text { 4) Test Tribal Reasoning }\end{array}$ & Experimental \\
\hline & & & & control \\
\hline
\end{tabular}

Secondly, the research community, Research sample and Sample's research community

the research community consists of is second grade students average jaw girls mean to the Directorate-General for education Baghdad/Karkh/3 academic year 2015/2016 where ksdia was chosen by the researcher for the following reasons: 1. show Cooperation of school management search procedures. 2. fit four people school grade average. As follows: (a) (32), Division (b) (35), Division (c) (33), Division (d) (34) freshman making it easy for the Finder to choose random groups (experimental and control) search sample is chosen randomly among four divisions were Division represents the experimental group (30) a student Division and (c) the control group (30) a student after excluding women students are from two divisions as in table (1)

\begin{tabular}{|c|c|c|c|c|}
\hline $\begin{array}{c}\text { Number of } \\
\text { female } \\
\text { students after } \\
\text { excluding }\end{array}$ & $\begin{array}{c}\text { Number } \\
\text { of } \\
\text { excluded } \\
\text { students }\end{array}$ & $\begin{array}{c}\text { Number of } \\
\text { female students } \\
\text { before } \\
\text { excluding }\end{array}$ & group & $\begin{array}{c}\text { Experimental } \\
\text { group }\end{array}$ \\
\hline 30 & 2 & 32 & $\mathrm{a}$ & Experimental \\
\hline 30 & 3 & 33 & $\mathrm{c}$ & controlled \\
\hline 60 & 5 & 65 & $\mathrm{a}+\mathrm{b}$ & group \\
\hline
\end{tabular}

equal sample: Equivalence Samples although the research groups have been selected from a harmonious society and social media converging, and randomization ensures equal elements of research groups but the researcher and an increase in concern for the safety of the experiment conducted the search collection items in equal Variables that thinks it may affect the outcome of the experiment because of individual differences between students:

1) Chronological age: Age of Tim (in moth) students ' ages were obtained from research groups, school records and calculate age in months until 15/2/2016 table 2 shows that.

2) Previous information: previous information knowledge test researcher in biology depend on identifying its textbooks and test consisted of (20) paragraph type multiple choice test covers the whole biology grade average as well as some questions First grade science article covers average test was introduced to a group of experts to validate its test has some acceptance by all the experts after making some adjustments.

3) Previous Academic achievement: students ' grades were obtained by science for first grade average for the academic year 2014/2015 from school records and data are presented in table 2.

4) The evidentiary standard deductive thinking dish thinking on research and collection by Haidar (researcher adopted) before starting the experiment Sunday $21 / 2 / 2016$, table 2 shows that the results showed equal two in the above variables table (2).

Table 2: Equivalent data of research collection contrast

\begin{tabular}{|c|c|c|c|c|c|c|c|}
\hline \multirow{2}{*}{$\begin{array}{l}\text { Significant at } \\
\text { level } 0.05\end{array}$} & \multicolumn{2}{|c|}{ T value } & \multirow[t]{2}{*}{ differences } & \multirow[t]{2}{*}{ Arithmetic mean } & \multirow[t]{2}{*}{ Number of female students } & \multirow[t]{2}{*}{ groups } & \multirow[t]{2}{*}{ variables } \\
\hline & tabular & calculated & & & & & \\
\hline \multirow[b]{2}{*}{ Not significant } & \multirow[b]{2}{*}{2} & \multirow{2}{*}{0,097} & 7,22 & 164,27 & 30 & Experimental & \multirow[b]{2}{*}{ Life time } \\
\hline & & & 5,98 & 164,10 & 30 & control & \\
\hline \multirow{2}{*}{ Not significant } & \multirow{2}{*}{2} & \multirow{2}{*}{$\mathbf{0 , 8 2 1}$} & 2,21 & 13,23 & 30 & Experimental & \multirow{2}{*}{ Previous info. } \\
\hline & & & 1,86 & 12,80 & 30 & control & \\
\hline \multirow{2}{*}{ Not significant } & \multirow{2}{*}{2} & \multirow{2}{*}{0,360} & 18,46 & 61,13 & 30 & Experimental & \multirow{2}{*}{$\begin{array}{c}\text { Previous } \\
\text { test }\end{array}$} \\
\hline & & & 16,64 & 59,50 & 30 & control & \\
\hline \multirow{2}{*}{ Not significant } & \multirow[b]{2}{*}{2} & \multirow{2}{*}{0,496} & 5,28 & 15,8 & 30 & Experimental & \multirow{2}{*}{ 4. Test tribal reasoning } \\
\hline & & & 4,00 & 15,2 & 30 & control & \\
\hline
\end{tabular}

\section{Research Requirements}

1) Select scientific article :

Scientific article which will study both groups look at Chapter 2 2015/2016 of medium grade textbook Fifth Edition 2014 m covering three good seasons respectively (Chapter VII/invertebrate Zoology) (Chapter VIII/zoology Nematodes) (chapter IX/relationships between organisms and their environment. (Shehab Ahmed et 2014.101.188).

2) Formulate behavioral purposes: it had been drafted (158) our divisive behavior by Bloom's taxonomy cognitive domain (Remember, understanding (absorb), application). Behavioral uses were presented to a group of experts and specialists in the field of education and psychology and methods of teaching science supplement (1) to find out how fit the cognitive levels in light of their opinions and their feedback has been making some adjustments and adjust the level measure for some of them to take reformulated Final.

3) Daily teaching plans: (20) teaching plan for the two groups (experimental and control) paradigm which were presented to A group of experts and specialists in methods of teaching science to demonstrate their performance and their feedback on the suitability and appropriateness for second grade students average notes was introduced and make some adjustments and then

\section{Volume 6 Issue 12, December 2017}




\section{International Journal of Science and Research (IJSR) \\ ISSN (Online): 2319-7064}

Index Copernicus Value (2016): 79.57 | Impact Factor (2015): 6.391

basically adopted in preparing the rest of daily teaching plans.

\section{Research Tools Setup}

requires current research based academic achievement and test builds (evidentiary thinking) by Haidar (2014).

1. build the achievement test: a test was built earlier for second grade students average depending on the content of the course of the last three seasons and behavioral uses prepared for that and keen researcher to test this test verifies the good attributes of objectivity and comprehensiveness, sincerity and constancy and the other properties.
A- test map preparation (table specifications): it has been set up which is schedule the last three chapters topics of biology book grade average and behavioral levels of bloom (remembering, understanding, application) and requests that specify the test paragraphs (40) paragraph after trading test With a number of biology teachers who teach biology grade average, behavioral uses weights calculated by percentages of behavioral objectives were chosen (40) served reject from a group of cognitive behavioral purposes (158) served in varied levels of behavior on a schedule Specifications table (3).

Table 3: Table of specifications for educational choice for biology

\begin{tabular}{|c|c|c|c|c|c|c|c|}
\hline \multirow{2}{*}{ total } & \multicolumn{3}{|c|}{ Objectives level } & \multirow{2}{*}{ percentage } & \multirow{2}{*}{ Number of lectures } & \multirow{2}{*}{ subject } & \multirow{2}{*}{ Chapters } \\
\hline & Applying & Perception & remembering & & & & \\
\hline 14 & 1 & 6 & 7 & $\% 35$ & 7 & Invertebrates & 7 \\
\hline 16 & 1 & 7 & 8 & $\% 40$ & 8 & nematodes & 8 \\
\hline 10 & 1 & 4 & 5 & $\% 25$ & 5 & relationships between organisms & 9 \\
\hline 40 & 3 & 17 & 20 & $\% 100$ & 20 & & total \\
\hline
\end{tabular}

B - drafting paragraphs test:-test paragraph for every purpose behavior commensurate with his level of knowledge on the schedule is the achievement test specifications (40) paragraph.

C - the test Validity: Test been ratified. expense test in my honesty and sincerity content through virtual showcase behavioral uses paragraphs to experts in biology and science teaching methods and calendar and measurement to check the wording of paragraphs testing and scientific accuracy and relevance of paragraphs with Behaviorism and the distribution of grades between paragraphs and logical and attractiveness of alternatives and the amount of coverage of the subject in the light of expert opinions and agreement over 90 adjusted some paragraphs and final draft was reached for testing as well as to adopt experimental map being over index test passages The content of the course and behavioral uses associated with that content test thus became sincere in its content.

\section{The application of the achievement test:}

the first exploratory sample application is made up of 30 second grade students from average to medium Khadija girls 4/4/2016 Monday to make sure the test instructions clearly formulate its legibility and the time it takes for the test Students ' day (30-50) minutes to answer all test passages and may select the time search lmgmoaiti Answer b (45) minutes to answer the achievement test paragraphs. The second exploratory sample application consisting of (100) a student of intermediate students Khadija girls on Sunday was 10/4/2016 patch test and treatment results statistically exploratory sample students grades was arranged from top notch was (33) to the lowest score (3) had been taking a percentage (27) Highest score to represent the Supreme group and 27 percent of the lowest grades to represent the minimum set high group ranging between $26-33^{\circ}$ the characteristics were developed as follows: plants difficult to test For Factor.

\section{Difficulty accomplishing paragraphs Hems}

The difficulty factor was calculated each paragraph using the difficulty factor coefficient is found to act difficult substantive paragraphs ranging from $(0,30-0,57)$ and this paragraph is acceptable.

\section{Power of the achievement test paragraphs highlighting:} Highlight force calculated each paragraph of the test using the equation of specific discrimination coefficient is found to distinguish between $(0,30-0,74)$ so that all paragraphs unacceptable primacy is acceptable if the discriminatory capacity greater than $(0,20)$. So all the achievement test paragraphs are acceptable in terms of discriminatory capacity.

\section{Test Reliability}

Test reliability is calculated by consistently test by using an equation (kiodor Richardson-20) found it equal to $(0,82)$ this indicates that the test with constant value.

Appendix (1) names of experts who retained the seeker in search procedures

\begin{tabular}{|c|c|c|c|c|c|c|c|}
\hline \multicolumn{4}{|c|}{ Type of sample } & \multirow{2}{*}{ Qualification } & \multirow{2}{*}{ Specialization } & \multirow{2}{*}{ Expert name } & \multirow{2}{*}{$ت$} \\
\hline 4 & 3 & 2 & 1 & & & & \\
\hline & $\sqrt{ }$ & $\sqrt{ }$ & $\sqrt{ }$ & $\begin{array}{l}\text { faculty of education for pure } \\
\text { science- Ibn al-Haitham }\end{array}$ & Physics Teaching methods & Prof. Magda Ibrahim Albawi & 1 \\
\hline$\sqrt{ }$ & & & & $\begin{array}{l}\text { faculty of education for pure } \\
\text { science- Ibn al-Haitham }\end{array}$ & $\begin{array}{l}\text { Evaluation and } \\
\text { measurements }\end{array}$ & Prof. DrIhsanolawi Nasser & 2 \\
\hline & $\sqrt{ }$ & $\sqrt{ }$ & $\sqrt{ }$ & $\begin{array}{l}\text { faculty of education for pure } \\
\text { science- Ibn al-Haitham }\end{array}$ & Biology Teaching methods & Prof Dr Fatima Abdul Amir & 3 \\
\hline & $\sqrt{ }$ & & $\sqrt{ }$ & $\begin{array}{l}\text { faculty of education for pure } \\
\text { science- Ibn al-Haitham }\end{array}$ & Biology science & $\begin{array}{c}\text { rof. Dr } \\
\text { Sabah Faraj }\end{array}$ & 4 \\
\hline
\end{tabular}

\section{Volume 6 Issue 12, December 2017}




\section{International Journal of Science and Research (IJSR) \\ ISSN (Online): 2319-7064}

Index Copernicus Value (2016): 79.57 | Impact Factor (2015): 6.391

\begin{tabular}{|c|c|c|c|c|c|c|c|}
\hline & $\sqrt{ }$ & $\sqrt{ }$ & $\sqrt{ }$ & $\begin{array}{l}\text { faculty of education for pure } \\
\text { science- Ibn al-Haitham }\end{array}$ & Teaching methods & $\begin{array}{l}\text { Assist. Prof. Dr Mohamed Ali } \\
\text { Habib. }\end{array}$ & 5 \\
\hline \multirow[t]{2}{*}{$\sqrt{ }$} & & & & $\begin{array}{l}\text { faculty of education for pure } \\
\text { science- Ibn al-Haitham }\end{array}$ & psychology & Assist. Prof. DrNaji Mahmoud Naji & 6 \\
\hline & $\sqrt{ }$ & & $\sqrt{ }$ & $\begin{array}{c}\text { faculty of education for pure } \\
\text { science- Ibn al-Haitham }\end{array}$ & Biology science & Prof. Assist. DrNahlaJassim & 7 \\
\hline$\sqrt{ }$ & & & & $\begin{array}{l}\text { faculty of education for pure } \\
\text { science- Ibn al-Haitham }\end{array}$ & psychology & $\begin{array}{l}\text { Prof. Assist. Dr. Jamal Dr. Hamid } \\
\text { Kassem }\end{array}$ & 8 \\
\hline \multirow[t]{2}{*}{$\sqrt{ }$} & & & & $\begin{array}{l}\text { faculty of education for pure } \\
\text { science- Ibn al-Haitham }\end{array}$ & psychology & Assist. Prof. DrNohaArifDarwish & 9 \\
\hline & $\sqrt{ }$ & $\sqrt{ }$ & $\sqrt{ }$ & $\begin{array}{l}\text { faculty of education for pure } \\
\text { science- Ibn al-Haitham }\end{array}$ & Chemistry teaching method & DrBasma Ahmad Mohamed & 10 \\
\hline$\sqrt{ }$ & & & & $\begin{array}{l}\text { faculty of education for pure } \\
\text { science- Ibn al-Haitham }\end{array}$ & psychology & $\begin{array}{c}\text { Assist. Assist. } \\
\text { DrMuntahamutasherAbdulsaheb }\end{array}$ & 11 \\
\hline \multirow[t]{5}{*}{$\sqrt{ }$} & & & & $\begin{array}{l}\text { faculty of education for pure } \\
\text { science- Ibn al-Haitham }\end{array}$ & psychology & Assist. DrJabbarWadiBahedh & 12 \\
\hline & $\sqrt{ }$ & $\sqrt{ }$ & $\sqrt{ }$ & $\begin{array}{l}\text { faculty of education for pure } \\
\text { science- Ibn al-Haitham }\end{array}$ & Biology teaching method & Assist. Dr Ahmed Obaid Hassan & 13 \\
\hline & $\sqrt{ }$ & $\sqrt{ }$ & $\sqrt{ }$ & Teacher Training Institute/Diyala & Physics teaching method & Assist. DrTHaney Hussein khaagy & 14 \\
\hline & $\sqrt{ }$ & $\sqrt{ }$ & $\sqrt{ }$ & $\begin{array}{l}\text { faculty of education University of } \\
\text { Almustansriyah- }\end{array}$ & $\begin{array}{l}\text { Mathematics teaching } \\
\text { method }\end{array}$ & Assist. Dr Ammar al-Janabi & 15 \\
\hline & $\sqrt{ }$ & $\sqrt{ }$ & $\sqrt{ }$ & $\begin{array}{l}\text { faculty of education University of } \\
\text { Alkofa- }\end{array}$ & Biology teaching method & Assist. Dr Abbas AbdulMahdi & 16 \\
\hline
\end{tabular}

The nature of the consultation:

1) Test information.

2) The achievement test.

3) Behavioural purposes.

4) Deductive thinking metric.

\section{Measure the evidentiary thinking}

because a measure is ready serve research purposes by (HaiderMaen, 2014) being applied to second graders Mediterranean and consists of (30) paragraph in two axes (deduction represents 15 paragraph), (induction represents 15) as well as on he enjoyed steady and true high in order Of the researcher and the researcher has certainly increased installation of sincerity and consistency and set the class range (0-30) (Haider, 2014:190).

\section{Experiment Test Application Procedures}

Experience is applied according to the following procedures:

1) Coordination with the Department of school and school districts to organize weekly schedule for research groups in one day to prevent deprivation sets of lessons in case there is an official holiday or occasion On that day, thus ensuring an appropriate functioning of faculty walk.

2) Use of materials, tools and images relating to the subject of biology are available in the school lab itself to both groups.

3) The actual search sample began teaching experimental groups and control on Sunday 21/2/2016 after applying the pretest standard deductive thinking.

4) Control groups were taught the regular way and learnerbased learning pilot by weekly 2 per group and was given the same duties, experience and educational activities.

5) After the end of the experiment the achievement test was applied to the experimental groups finalized and officer on Monday 2/5/2016.

6) Apply deductive thinking scale test post on Wednesday 4/5/2016.

\section{Statistical Means}

1) T-test two independent counting on:-

a) Equal groups of control and experiment groups.

b) Comparison of experimental groups and students grades averages officer.

2) An equation difficult to detect difficulties accomplishing test paragraphs.

3) Discrimination coefficient equation to find discriminatory power of the achievement test and measure the evidentiary thinking.

4) Equation (cooder richardson-20) to calculate the factor the achievement test and deductive thinking metric.

5) Erroneous alternatives effective equation of the achievement test.

$$
t=\frac{\overline{X_{1}}-\overline{X_{2}}}{\sqrt{\left(n_{1}-1\right) S_{1}^{2}+n_{2}-n_{1} S_{2}^{2}\left(\frac{1}{n_{1}}+\frac{1}{n_{2}}\right)}}
$$

-Difficulty Factor $=$ summation of incorrect answers/ summation of (correct answer + incorrect answer)

$\mathrm{T}=\mathrm{S}-\mathrm{A}-\mathrm{S} * \mathrm{D} / 0.5(\mathrm{~A}+\mathrm{D})$

\section{Homogeneity Factor $=\mathrm{T} / \mathrm{T}-\mathbf{1} *$ Total $\mathrm{X} * \mathrm{Y} / \mathrm{A}^{2}$}

NAM-NDM / $0.5(A+D)$

(Aldulaimy and Mahdawi,2005).

\section{Results and Interpretation}

After finishing the experiment according to the steps mentioned earlier, analyzed the results of the current search to identify the impact of learner-based learning in biology gets second grade students average and evidentiary endure through check The vacant premises as follows: 


\section{International Journal of Science and Research (IJSR) \\ ISSN (Online): 2319-7064 \\ Index Copernicus Value (2016): 79.57 | Impact Factor (2015): 6.391}

1. Education: for the purpose of verifying the first hypothesis which States that there is no statistically significant difference at the level indication (0.05) between average collection of experimental group students who studied under the impact of learner-based learning and student achievement scores average Control group, who studied the way the achievement test routine in biology). Using t-test (T-test) as shown in the table (4) t value is greater than the value at the table indication $(0.05)$ and the degree of freedom (58) and that means having a statistically significant difference in academic achievement and for the experimental group.

Table 4: The arithmetic mean of the two pilot officer in the test collection

\begin{tabular}{|c|c|c|c|c|c|c|}
\hline \multirow[b]{2}{*}{ Statistical significant at $(0,05)$} & \multicolumn{2}{|c|}{ T value } & \multirow[b]{2}{*}{ Standard deviation } & \multirow[b]{2}{*}{ Arithmetic mean } & \multirow{2}{*}{ Number of persons } & \multirow[b]{2}{*}{ groups } \\
\hline & tabular & calculated & & & & \\
\hline \multirow{2}{*}{ significant at control group } & \multirow{2}{*}{2,00} & \multirow{2}{*}{3,90} & 5,78 & 24,53 & 30 & experimental \\
\hline & & & 6,51 & 18,33 & 30 & control \\
\hline
\end{tabular}

\section{Deductive thinking}

for the purpose of verifying the second hypothesis States that there is no statistically significant difference at the level indication (0.05) between the average grades of students who studied under the experimental group based learning paradigm learner and average control group students who studied under The usual way to measure constructive thinking. Using t-test as described in table (5) t value is greater than the value gap that means table statistically significant evidentiary thinking and for the experimental group.

Table 5: $\mathrm{t}$ value is greater than the value gap that means table statistically significant evidentiary thinking and for the experimental group.

\begin{tabular}{|c|c|c|c|c|c|c|}
\hline \multirow{2}{*}{ Statistical significant at $(0,05)$} & \multicolumn{2}{|c|}{$\mathrm{T}$ value } & \multirow{2}{*}{ Standard deviation } & \multirow{2}{*}{ Arithmetic mean } & \multirow{2}{*}{ Number of persons } & \multirow[b]{2}{*}{ groups } \\
\hline & tabular & calculated & & & & \\
\hline \multirow{2}{*}{ significant at control group } & \multirow{2}{*}{2,00} & \multirow{2}{*}{3,20} & 3,438 & 17,93 & 30 & experimental \\
\hline & & & 3,413 & 15,06 & 30 & control \\
\hline
\end{tabular}

\section{Interpretation of results}

The results showed superiority of the experimental group students who studied as a model-based learning on the learner to control group students who attend the regular way in biology collection table (4) researcher attributed the high level of collection of experimental group students Compared to the control group students collection to use existing humanitarian curve on the learner in the learner the opportunity to interact with the content of the course where I get knowledge as in the normal way ready. Based learning paradigm, the learner has a positive effect in improving deductive thinking by increasing self confidence and the many questions and inquiries.

\section{Conclusions}

Conclusion in light of the results of the current search can infer:

1) Having a positive impact on learner-based learning model used in raising academic achievement compared to the usual way.

2) Having a positive impact on learner-based learning model used in deductive thinking level rise.

\section{Recommendations}

In light of the results of the current search researcher recommends the following:

1) The teaching staffs training on non-traditional teaching methods and techniques, including learner-based learning paradigm in biology teaching.

2) Encourage students to laboratory activities that increase their performance and develop deductive thinking.

\section{Proposals}

Proposals are Suggestions in light of the current search results following studies researcher proposes:

1) Conduct a study similar to current research in other subjects and study stages.

2) A similar study to compare schools, boys and girls.

3) Conduct a study similar to current research in other dependent variables such as problem solving, critical thinking, scientific thinking.

\section{References}

[1] Abu Jado, Saleh Mohammed Ali, (2009) Educational Psychology, Dar Al-Masirah, Amman, Jordan. IAhmad KhairiKazem and Sa'ad Y. Zaki (1973) Teaching Science, I 1, Dar al-Nahda al-Arabiya, Egypt. ال

[2] Al-Babaoui, Magda Ibrahim and Mehdi AlwanAbboud (2004) 'Teaching practices of a member of the organizationIn light of the education year ', Wasit magazine, p (1), Wasit University. أم

[3] Ambo Saidi, Abdullah and Sulaiman Al-Balushi, (2011) Methods of Teaching Science, 2, Dar Al-Masirah for Publishing, Distribution and Printing, Amman, Jordan.

[4] Al-Khazraji, NasifJassimObaid (2009) The Impact of the Model of Structural Learning and Collaborative Learning in the Modification of the Misconception of Physical Concepts and Explanatory Thinking among Female Students in the Institute of Teacher Preparation, Unpublished Dissertation, Baghdad University, Faculty of Education Ibn Al-Haytham.

[5] Al-Khawaldeh, Muhammad Mahmood et al. (1995), General Teaching Methods, I, Bookwriters.

[6] Al-Dulaimi, IhsanAliwi and Adnan Mahmoud AlMahdawi, (2005) Measurement and Evaluation in the 


\section{International Journal of Science and Research (IJSR) \\ ISSN (Online): 2319-7064}

Index Copernicus Value (2016): 79.57 | Impact Factor (2015): 6.391

Educational Process, No. 2, Ahmed Al-Dabbagh Library, Iraq.

[7] Alswror, Nadia Hale (2005) Teaching Thinking in the School Curriculum, I 1, Dar Wael, Amman.

[8] Al-Suasafah, Abdul Rahman Ibrahim, (2005) Department of Education and Education, Dar Yazid, Karak.

[9] Al-Sagher, Ali bin Muhammad, and Saleh bin Abdulaziz al-Nassar, (2002)-Teacher Practice in the Light of theories of Learning', Journal of Reading and Knowledge, p. 18 - Faculty of Education, Ain Shams University, Cairo.

[10] ALAffoons, Nadia Hussein, and Batul Mohammed JassimDaini, (2008) Effectiveness of learner-based learning in the achievement of female The second stage at secondary school and their motivation towards biology, Journal of Educational and Psychological Sciences, No. (6), Baghdad.

[11] Al-Issawi, Abdul Rahman Mohammed, (2008) Psychology in the field of education, modern education and the development of scientific thinking, 1, Dar alNahda al-Arabiya, Beirut.

[12] Al-Najidi, Ahmad et al. (2005) Recent trends in science education in the light of international standards and the development of thought and theory, 1, Dar Al-Fikr AlArabi for Printing and Publishing, Amman.

[13]lwaidi, Zaid, (2005) Modern Methods in Teaching Science, I 1, University Book House, Al Al Ain, United Arab Emirates.

[14] Awafi, Radi (1998) Introduction to Psychology, I 3, Bibliotheca Alexandrina, Cairo.

[15]Badr, Buthaina Mohamed Mahmoud (2010) Effectiveness of the use of the strategy of Wassili enrichment in the teaching of mathematics on the development of the skills of reasoning reasoning and achievement and motivation for academic achievement of students in the preparatory stage, Arab studies in education and psychology, Volume (4), No. (4), October 6, Riyadh.

[16] Al Badawi, Ramadan Saad, (2009) Introduction of systems for the dissemination of curriculum and curriculum, I 1, Dar Al-Fikr, Amman.

[17] HaidarMaan Ibrahim, (2014) Effect of the retrospective table on the collection of biology and reasoning thinking among second grade students,Unpublished Master Thesis, Baghdad University, College of Education for Pure Sciences / Ibn al-Haytham.

[18] Khader, Fakhri, Rachid, (2006) Methods of Teaching Social Studies, 1, Dar Al-Massirah for Publishing, Distribution and Printing, Amman, Jordan.

[19]Zidane, Muhammad Mustafa, (2008), Dictionary of psychological and educational terms, Dar Al-Shorouk, Jeddah.

[20] Saeed, Abdul Aziz, (2007) Teaching Thinking and Skills, 1, Dar Al-Thaqafa, Amman.

[21] Shahab Ahmad Salman et al., (2014) Biology for the second intermediate grade, i5, Ministry of Education,Directorate General of Curricula, Baghdad.

[22] Abdul Aziz, Saeed, (2009) Teaching thinking and skills practical exercises and applications, I 2, Dar Al-Thaqafa for Publishing and Distribution, Amman.

[23] Adas, Abdul Rahman, Yusuf Qatami, Abdullah Menizel, and Yusuf Khalid, (2002) Educational
Psychology, I 2, Al Quds University, Amman, Oman. Attia, Mohsen Ali (2008) Recent Strategies in Effective Teaching, 1, Sana'a House, Amman.

[24] Aiadah, Lamia Hassan Kassem, (2013), The strategy of teaching reciprocal in the achievement of students in the first grade intermediate in mathematics and their explanatory thinking, unpublished master thesis, Mustansiriya University, Faculty of Basic Education.

[25] Qatami, Yousef Mahmoud, and NargisHamdi, (1994) Education program, teaching design,1, Al-Quds Open University, Amman. طatami and Naifah, (1998) Teaching Methods Classroom, 2nd Floor, Dar AlShorouq, Amman.

[26] MadkhalyAbeer, (2009) The Effectiveness of Brainstorming in the Teaching of Geography in the Acquisition of Geographical Concepts and the Development of Inductive Thinking among First Grade Students in Jazan Region, Unpublished Master Thesis, Girls College of Education, King Khalid University, Saudi Arabia.

[27] Hamshari, Omar Ahmed (2001) Introduction to Education, 1, Dar Safa, Amman.-

[28] Alder man,M.Kay(2007), Motivation for Achievement : Possibilities for teaching and Learning, $2^{\text {nd }}$ Edition.

[29] Bihler, R.F Snow man, J. (1990), “ Psychology Applied to teach" Houghton Mifflin, Bostan.

[30] Rogers, C.R.,(1993) : “Freedom to Learn for the 8 os", Charles E.Merrill, Columbus.

Volume 6 Issue 12, December 2017

www.ijsr.net

Licensed Under Creative Commons Attribution CC BY 